Michą PAszKowsKi

Uniwersytet Jagielloński, Kraków

\title{
Ksztaltująca się gospodarka sieciowa jako pole badawcze geografii przemysłu
}

Zmiany struktury popytu konsumenckiego w najwyżej rozwiniętych krajach pociągają za sobą wiele istotnych konsekwencji przestrzennych. Dzisiejsi konsumenci nie zadają sobie pytania: „co chciałbym mieć, czego jeszcze nie mam?”, lecz „,co chciałbym przeżyć, czego jeszcze nie doświadczyłem?” Nastąpiło przeniesienie nacisku z gromadzenia dóbr materialnych na absorpcję stylów życia. Zachodzi proces komercjalizacji doznań, przeżycia stają się oferowanym produktem w postaci np. sposobów spędzania wolnego czasu (produkty „pakietowe” turystyki, galerie handlowe) czy sprzedaży dostępu do stylów życia (gated communities). Tak charakteryzuje istotne cechy nowej postaci gospodarki Jeremy Rifkin w swej książce Wiek dostępu. Nowa kultura hiperkapitalizmu, w której ptaci się za każda chwilę życia (2003). Przytacza dalej dwie ważkie opinie: „W końcu przekroczymy barierę współczesnej ekonomii i znajdziemy się poza orbitą wyobraźni dzisiejszych ekonomistów; staniemy się pierwszą kulturą w dziejach ludzkości, która zacznie wykorzystywać wysoką technologię do wytwarzania tego najbardziej przemijającego, a jednak najtrwalszego z produktów, jakim są ludzkie przeżycia” (Alvin Toffler); „Przeżywane doznania są ostatnim stadium komercjalizacji, inaczej mówiąc, są wyrobem finalnym cyrkulacji kapitału” (Guy Debord). Rodzi się zatem nowa branża: gospodarka ludzkich doznań i doświadczeń.

Wiele refleksji istotnych dla geografii przemysłu przynoszą także inne opracowania ekonomistów i socjologów, którzy dostrzegli symptomy powstawania nowego kształtu gospodarki (np. Luttwak 2000, Korten 2002). Tym refleksjom poświęcone zostały poniższe rozważania.

Czy wytwarzanie produktów materialnych zostanie w przestrzeni gospodarczej świata zdominowane przez działalność polegającą na oferowaniu produktów w postaci ludzkich doznań i doświadczeń? Czy ewolucja struktury potrzeb konsumentów spowoduje nieoczekiwane przekształcenia roli przemysłu w gospodarce?

Jeśli bowiem ,przedmiotem działalności przemysłu jest wydobycie bądź pozyskanie surowców mineralnych, roślinnych i zwierzęcych oraz przetwarzanie ich, za pomocą obróbki fizycznej lub chemicznej, na wyroby gotowe służące zaspokojeniu potrzeb człowieka" (Kortus 1986), to ważną okolicznością stało się to, że przemysł uzyskał możliwość wpływania na strukturę potrzeb społecznych (np. poprzez mass media), a nawet generowania nowych potrzeb, których zaspokajanie jest dla przemysłu zyskowniejsze. 
Powstaje sprzężenie zwrotne, które wraz z dynamizującym wpływem postępu technicznego, stale wymuszającym sukcesję gałęzi wiodących, utrudnia interpretację przekształceń przemysłu i odróżnianie działalności przemysłowej od innych rodzajów działalności gospodarczej, dlatego istotne jest stałe unowocześnienie klasyfikacji całej gospodarki i samego przemysłu, tak aby m.in. uniknąć nieporozumień wynikających z różnych zakresów pojęciowych terminów przemysł i industry. Jeśli przyjąć, że industry to wszelka działalność nastawiona na zysk prowadzona na wielką skalę przy użyciu standardowych procedur i dająca standaryzowany produkt, to $\mathrm{np}$. aircraft industry wytwarzając samoloty należy do przemysłu, natomiast airline industry, zajmująca się działalnością przewoźników lotniczych reprezentuje transport, zaś tourist industry, hotel industry, finance industry etc. odnoszą się do różnych działów usług. Posługiwanie się kalkami pojęciowymi z użyciem polskiego słowa przemysł prowadzi do szkodliwych nieporozumień typu „przemysł hotelarski”.

Z natury rzeczy klasyfikacje nie nadążają za pojawianiem się nowych produktów i nowych sposobów gospodarowania. Wystarczy sobie uświadomić, że jeszcze 100 lat temu nie istniał przemysł samochodowy, choć budowano już te pojazdy w licznych warsztatach, które kojarzono z innymi istniejącymi wówczas gałęziami przemysłu i rzemiosła. Podobnie jest współcześnie z branżą IT (Information Technologies).

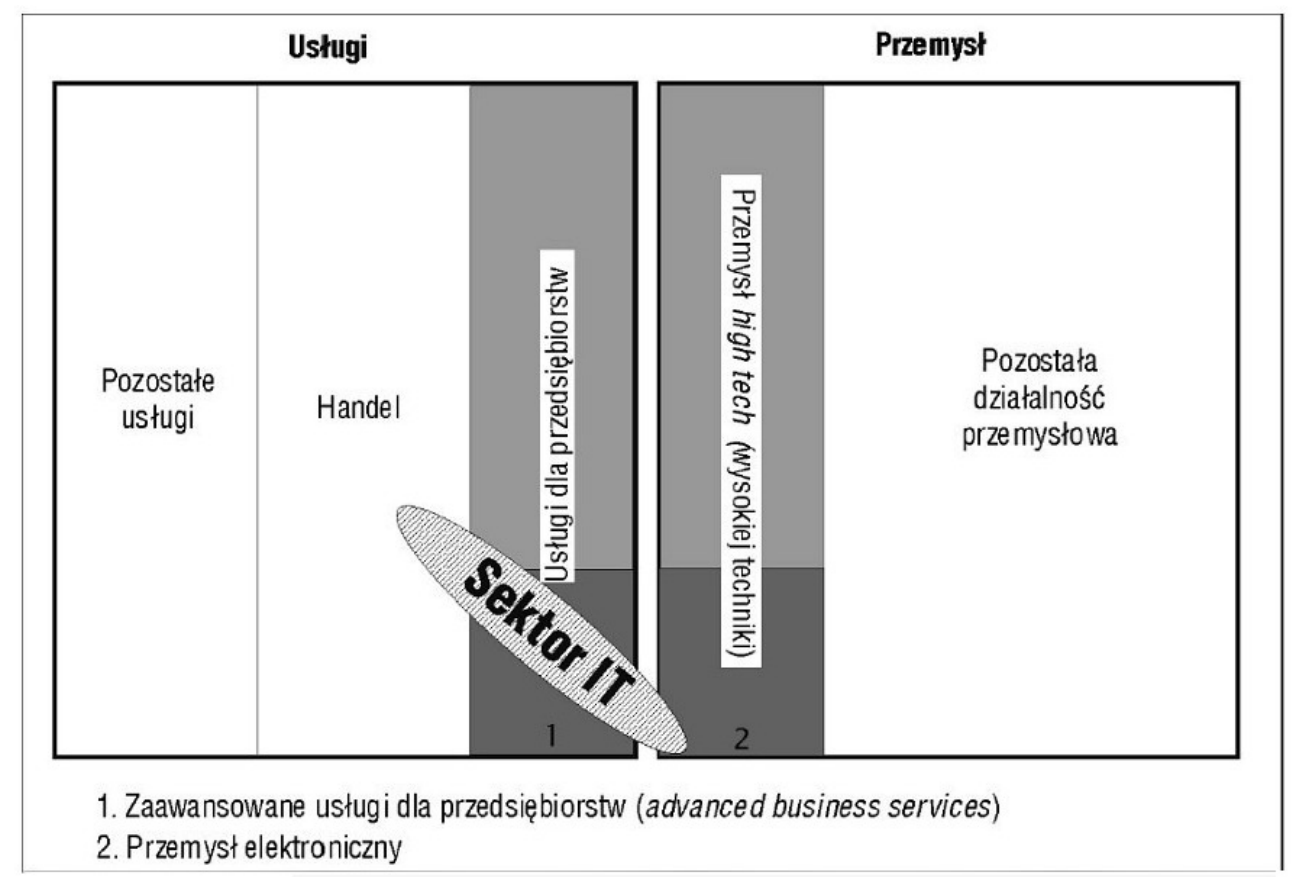

Ryc. 1. Sektor Information Technologies (IT) w relacji do przemysłu i usług Źródło: Micek 2006

Jeśli geografia przemysłu bada funkcjonowanie przemysłu w przestrzeni (Kortus 1986), to pojawiają się problemy z umiejscowieniem przejawów tego funkcjonowania w przestrzeni geograficznej. Struktura statystyki gospodarczej, z której danych korzysta geografia przemysłu, była usankcjonowana faktem lokalizowalności działalności gospodarczej na określonym terytorium (ośrodek, okręg, region, kraj). 
W gospodarce rynkowej decydujące było umiejscowienie własności majątku trwalego, który umożliwił powstanie danego produktu czy usługi. W trakcie industrializacji, w epoce rosnącego znaczenia przemysłu w strukturze gospodarki pozycja przedsiębiorcy (lub innych podmiotów gospodarujących, np. państwa) była określona w relacji własności poprzez posiadanie kapitału rzeczowego (maszyn, nieruchomości i ziemi), zatrudnianie pracowników, zarządzanie procesem produkcji, dystrybucję dóbr i usług.

Do takiej sytuacji dostosowane były mierniki tradycyjnie używane do pomiaru wielkości przemysłu, takie jak: liczba przedsiębiorstw, przeciętna liczba zatrudnionych, wartość produkcji (gross output), wartość dodana, wartość majątku trwałego, które np. w przypadku Industrial Statistics Database (UNIDO 1996) były odniesione do terytorium kraju.

Istotą kształtującej się gospodarki sieciowej jest zamiana relacji sprzedawca-nabywca charakterystycznej dla gospodarki rynkowej na relację dostawca-użytkownik realizowaną w skomplikowanej sieci powiązań.

Przekształceniom tym towarzyszą:

- spadek znaczenia kapitału rzeczowego,

- metamorfoza produktów w czyste usługi,

- wzrost znaczenia posiadania własności intelektualnej,

- zmiana perspektywy biznesu z produkcji na marketing,

- ciągła dematerializacja dóbr,

- komercjalizacja stosunków międzyludzkich i ludzkich doświadczeń (Rifkin 2003).

Przymiotnik ,sieciowy” rozumiany jest zarówno w sensie technologicznym, jak i organizacyjnym - w postaci sieci zależności i relacji.

Większość firm zależy obecnie od nowoczesnych technologii i usług telekomunikacyjnych. Ich dostawcami są prywatne sieci telekomunikacyjne tworzące nowe wspólnoty interesów, które są coraz słabiej związane z terytorium. Deregulacja i komercjalizacja światowych systemów telekomunikacji oraz radia i telewizji pozbawiają państwa możliwości nadzoru i kontroli transmisji na ich własnym terenie.

Coraz powszechniejsze stosowanie tzw. pracy zdalnej ma również swoje konsekwencje przestrzenne. Rola państwa narodowego maleje, jest to szczególnie znamienne w kwestii poboru podatków, ponieważ coraz więcej rodzajów działalności gospodarczej odbywa się na podstawie kontraktów i relacji w przestrzeni wirtualnej.

Dlatego władzom skarbowym poszczególnych krajów jest coraz trudniej ustalić, w którym miejscu przestrzeni geograficznej została wytworzona wartość dodana, a co za tym idzie, rząd którego państwa ma prawo do poboru podatku.

Wszystko to skłania do diagnozy: działalność w gospodarce sieciowej jest coraz trudniej lokalizowalna w przestrzeni geograficznej.

W gospodarce sieciowej majątek trwały jest traktowany nie jako fundament działalności gospodarczej, ale jako składowa kosztów. Stąd tendencja do wyzbywania się majątku trwałego, w tym produkcyjnego, ponieważ w ramach outsourcingu można zlecić wykonanie dowolnej produkcji komuś, kto specjalizuje się w wynajmowaniu czasu pracy maszyn i urządzeń do produkcji. Pojawiło się również zjawisko w pewnym sensie odwrotne do outsourcingu, tzw. podmontaż, gdy na liniach produkcyjnych danego wytwórcy montaż prowadzi zewnętrzna, wyspecjalizowana firma (Wiedermann 2006).

Udostępnianie maszyn i urządzeń do produkcji ma coraz więcej cech usługi, a usługi odgrywają dominującą rolę w gospodarce krajów rozwiniętych. Cechy usług jako towaru są charakterystyczne: nie mają cech własności, nie można ich posiadać, gromadzić ani dziedziczyć, 
ponieważ istnieją tylko w momencie świadczenia. W gospodarce usług towarem jest czas, a nie miejsce czy przedmioty.

W tych warunkach istotne są nie relacje własności rzeczy, ale relacje udostępniania, a w tych liczą się wartości niematerialne: know-how, schematy organizacyjne, zestawy procedur postępowania, czyli wartości informacyjne. Siłę ekonomiczną ma nie ten, kto bezpośrednio posiada i kontroluje majątek trwały służący do działalności gospodarczej, lecz ten, kto kontroluje sposób jego użycia, tj. sposób wykorzystania dóbr niematerialnych, takich jak patent, znak towarowy, pomysł, procedury operacyjne. Ważniejsze staje się nie to, na czym (na jakich maszynach i urządzeniach) produkować, ale co produkować, bo cechy produktu (m.in. zawarte w nim nowe pomysły) decydują o jego przewagach konkurencyjnych.

Z punktu widzenia przedsiębiorcy cała przestrzeń krajów rozwiniętych i nowo przemysłowych jest praktycznie jednorodna pod względem możliwości dostępu do urządzeń produkcyjnych o odpowiednim standardzie technicznym. Dlatego lokalizacja miejsca produkcji wiąże się z dążeniem do zapewnienia stabilności parametrów jakościowych produkcji, a także do redukcji pozostałych kosztów (siły roboczej, transportu itd.). Posiadanie własnego majątku produkcyjnego przestaje mieć kluczowe znaczenie. Miejsce powstania wartości dodanej staje się coraz trudniej lokalizowalne i coraz częściej generowanie istotnej jej części jest wiązane z miejscem powstania projektu wyrobu (czy jego prototypu), a nie miejscem jego masowej produkcji. Firma Nike (producent artykułów sportowych) „nie posiada fabryk, maszyn, sprzętu ani nieruchomości. Zamiast tego zorganizowano w Azji Południowo-Wschodniej ogromną sieć dostawców nazwanych partnerami produkcyjnymi, którzy produkują setki wzorów obuwia i innych artykułów sportowych" (Rifkin 2003).

Rośnie też znaczenie miejsc integracji wyrobów w systemy (całości funkcjonalne). To integratorzy, a nie producenci uzbrojenia, przyrządów celowniczych, aparatury naprowadzania i sprzętu nawigacyjnego decydują o kontraktach zbrojeniowych, takich jak projekt bojowej wersji śmigłowca „Huzar”.

O potędze ekonomicznej decydują wiedza i idee - ale poprzez posiadanie własności: patentów, praw autorskich, znaków handlowych, tajemnic firmowych, rozeznania we wzajemnych relacjach firm. Posiadanie tej własności stało się kluczowe, odkąd zmieniło się podejście do rezultatów odkryć przyrodniczych. Kiedy w XIX wieku chemik odkrywał nowy pierwiastek w przyrodzie, wolno mu było opatentować opracowany przez siebie sposób jego wydobycia i rafinacji, ale nie mógł opatentować pierwiastka jako takiego - prawo patentowe na całym świecie nie uważa odkryć przyrodniczych za wynalazki. Jednak pod naciskiem wielkich korporacji biotechnologicznych w 1987 roku Amerykański Urząd Patentowy zmienił zasady dotyczące odkryć przyrodniczych, ogłosił radykalne rozporządzenie, zgodnie z którym istotne własności życiowe części składowych istot żywych - genów, chromosomów, komórek i tkanek - mogą podlegać opatentowaniu, a więc można je uważać za własność intelektualną tego, kto pierwszy je zidentyfikuje, opisze cechy i funkcje oraz znajdzie ich użyteczne zastosowanie rynkowe (Rifkin 2003). Na przykład opatentowane ziarno siewne firmy Monsanto ma takie własności, że nowe ziarno zebrane w czasie żniw nie może być użyte przez rolnika jako materiał siewny w następnym roku, ponieważ własność kiełkowania należy do właściciela patentu (musi być przez niego aktywowana lub odblokowana). Tak więc farmer uzyskuje jedynie krótki dostęp do cudzej własności intelektualnej, bo ziarno siewne nie jest sprzedawane w tradycyjnym tego słowa znaczeniu, lecz dzierżawione na jednorazowe użycie w jednym okresie wegetacyjnym. 
Najistotniejsza zdolność do generowania zysków (i tym samym wartości dodanej, w której udział kosztów osobowych stale maleje) tkwi zatem we własności intelektualnej, którą jako wartość informacyjną niełatwo uprzedmiotowić i zlokalizować w przestrzeni geograficznej. Stanowiąc jednak tajemnicę firmy, może być ta własność utożsamiana z lokalizacją siedziby zarządu firmy albo jej ośrodka komputerowego przechowującego bazy danych przedsiębiorstwa.

Aby móc odpowiedzieć na pytania zadane na początku niniejszych rozważań i badać funkcjonowanie przemysłu w przestrzeni gospodarki sieciowej, geografia potrzebuje nowych narzędzi, np. lokalizacji własności intelektualnej (postulat miernika wartości rynkowej własności intelektualnej, jej umiejscowienia w siedzibie zarządu korporacji zawłaszczającej wartości informacyjne itd.), a szerzej aparatu pojęciowego do uchwycenia relacji zachodzących w sieciach w odniesieniu do przestrzeni geograficznej (topologia relacji sieciowych, np. w postaci zastosowania teorii grafów).

\section{Literatura}

Luttwak E. 2000, Turbokapitalizm. Zwycięzcy i przegrani światowej gospodarki, Wydawnictwo Dolnośląskie, Wrocław

Korten D.C. 2002, Świat po kapitalizmie. Alternatywy dla globalizacji, Stowarzyszenie Obywatel, Łódź Kortus B. 1986, Wstęp do geografii przemystu, PWN, Warszawa

Micek G. 2006, „Czynniki i mechanizmy koncentracji przestrzennej firm informatycznych w Polsce”, Instytut Geografii i GP UJ (rozprawa doktorska)

Rifkin J. 2003, Wiek dostępu. Nowa kultura hiperkapitalizmu, w której płaci się za każda chwilę życia, Wydawnictwo Dolnośląskie, Wrocław

UNIDO Industrial Statistics Database INDSTAT 3, 1996 (i późniejsze), UNIDO, Industrial Statistics Branch, Vienna

Wiedermann K., 2006, „Czynniki i skutki rozwoju przemysłu motoryzacyjnego w skali lokalnej i regionalnej na przykładzie województwa śląskiego", Instytut Geografii i GP UJ (rozprawa doktorska)

\section{Emerging network economy as a research field of geography of production}

Geographical analysis of new socio-economic phenomena is often triggered by considerations made by researchers in the fields of economy and sociology. Network economy is an example widely presented in numerous works, e.g. The Age of Access: The New Culture of Hypercapitalism Where All of Life is a Paid-for Experience by Jeremy Rifkin.

In the networked world, the ground of primary commerce is moving from geography to cyberspace - where GDP is now predominantly immaterial and based on ownership of intellectual property. Market transactions of buyers and sellers who exchange produced goods and services for profit are now being replaced by network relationships between suppliers and users - servers and clients. The new way of life is characterized by the dematerialization of goods (even of money) and their metamorphosis into pure services, the rise of networks, and a shift in commerce from production to marketing. An example of a significant method of claiming intellectual property rights and revenue from farmers were terminator seeds developed by Monsanto. The seeds were bio-engineered to be sterile, so that instead of harvesting seeds at the end of one crop season to be used for the next, the farmer would have no choice but to turn to Monsanto for seeds for the next year crop. Outsourcing has become a corporate substitu- 
tion of internal ownership of physical capital and operations for access to resources and processes from outside suppliers.

In the times of market economy, the localizability of tangible capital and production processes in geographical space was the decisive factor which allowed geographical analysis. Nowadays more sophisticated tools of geographical research should be developed to study economic phenomena in various networks, e.g. the new implementation of topology of network relations. 